\title{
New Consumer Products Branding, Packaging and Labeling in Nepal
}

\author{
Bed Nath Sharma
}

\begin{abstract}
ABSTRECT
This paper focuses on existing practice of branding, packaging and labeling of new products in consumer product manufacturing units .Product identification is not possible without brand name. Protection of product is also equally important to provide quality product for consumer satisfaction. Information regarding the product such as: ingredents, guidelines to use, price, produced and expiry date etc. are also concerned subject of the potential buyer. All these aspects have to be considered for effective promotion of product. It is useful for immediate introduction and recovery in the market by a new product.
\end{abstract}

Key words : Product identification, promotion, protection, information, consumer satisfaction etc.

\section{Background}

Market is a prime challange to a manufacturer in this competitive environment. Consumer needs are changing continuously. Buyers are in search of useful products to satisfy their needs and wants. Companies are continuously trying to offer more valuable unique products to the potential buyers. In this context, to offer a useful new product that can be easily identified in the market is possible through suitable brand name. Besides this consumer awareness is increasing, they like to know other information regarding the quality and use of products. Similarly product success and effective promotion is not possible without proper packaging. Quality products have to be delivered safely to the buyers in convenient market place. Many consumer products are produced and commercialized in Nepal. Manufacturing units are using the brand name, packaging and labeling. Real practice on these aspects was unknown. Factual findings can support to take better decision for effective use of them.

\section{Study Methods}

Descriptive presentation of facts collected through questionnaire survey concerned with different section of consumer new products (soap, biscuit, noodles, cigarettes and cold drinks) is the methodiology followed in the study. The survey covered thirty-two new 
products of different eighteen manufacturing units. The respondents sampled to fill-up the questionnaire were eighteen line managers taking the responsibility of marketing including new product planning and development. Besides this, thirteen top level management authorities of the units were also interviewed to achieve the objectives of the study.

\section{The Theory}

A brand is a name, term, sign, symbol or design or combination of them, intended to identify the goods or services of one seller or group of sellers and to differentiate them from those of competitors (Kotler, 1996:444). Main reasons of branding are product identification, quality consistency, promotion, efficiency, legal protection, social well-being, value building, product image/personality development, product positioning, brand loyalty, line addition, prestige and status etc. But high cost, low quality, perishable products, homogeneous products and legal formalities may be the causes of not branding the product (Koirala, $2006: 6-8$ ). Further more, a brand may be manufacturer's brands, distributor's or private brands, licensed brand on the basis of ownership but it may be individual brand names, a blanket family names, separate family names and company trade name combined with individual product names on the basis of product line. It should have the features as brevity, distinctiveness, adaptable to new products, reflect product attributes, capable of legal protection, relevant and appropriate for product positioning (Agrawal, 2004:195-201).

As a fifth $\mathrm{p}$ of marketing, packaging refers to the activities of designing and producing the container or wrapper for a product. It may be primary, secondary, and shipping to perform the objectives as containment, protection, identification, communication, promotion and product differentiation. Good packaging also provide information based on truth, it must be economical, attractive, convenient, protective and transparent (Koirala, 2005: 8-11).

A label is a simple tag attached to a product or an elaborated designed graphic that is the part of the package. It identifies, grade, scribe and promote the product by providing the information to the buyer. It may be brand labels, grade labels and descriptive labels (Kotler and Armstrong 2005: 316).

\section{The Research}

\section{Branding Practice of New Products}

The research mainly focused on brand strategy, planning, use of brand, perceived value of brand, considerations to use the brand and other aspects of brand utility. It provides the knowledge about the situation of brand name using practice and perception by Nepalese consumer goods manufacturing units. 
New consumer product industries $(81.25 \%)$ have brand strategy. They think and plan for brand. This indicates that manufacturers perceive the value of a brand name. They use the brand for product identification, promotion, product positioning, to create brand loyalty, quality assurance etc. It help to achieve the recovery in the market rapidly.

\section{Table 1}

\section{Types of brand used}

\begin{tabular}{|c|c|c|c|c|c|c|c|}
\hline S.N & Types of Brand & Soap & Biscuit & Noodles & Cigarette & $\begin{array}{c}\text { Cold } \\
\text { Drink }\end{array}$ & Total \\
\hline a. & Individual brand name & 2 & 6 & 4 & 5 & 2 & 19 \\
& & $(20)$ & $(75)$ & $(50)$ & $(62.50)$ & $(66.67)$ & $(51.35)$ \\
& A blanket family name of & 4 & - & - & - & - & 4 \\
c. & $(40)$ & $(0)$ & $(0)$ & $(0)$ & $(0)$ & $(10.81)$ \\
& Separate family name of all & - & - & - & 3 & - & 3 \\
d. & products & $(0)$ & $(0)$ & $(0)$ & $(37.50)$ & $(0)$ & $(8.10)$ \\
& Company trade name & 4 & 2 & 4 & - & 1 & 11 \\
& combined with individual & $(40)$ & $(25)$ & $(50)$ & $(0)$ & $(33.33)$ & $(29.72)$ \\
e. & products names & & & & & & \\
& & & & & & & \\
fistributor's brand & - & - & - & - & - & - \\
\hline & No brand is used & - & - & - & - & - & - \\
\hline & Total & 10 & 8 & 8 & 8 & 3 & 37 \\
& $(100)$ & $(100)$ & $(100)$ & $(100)$ & $(100)$ & $(100)$ \\
\hline
\end{tabular}

Above table 1 shows that most of the soap industry uses a blanket family name of all products and company trade name combined with individual products name. But most of the biscuit, cigarette, and cold drink industries use individual brand name. It is also seen that most of the noodles industry use individual brand name as well as company trade name combined with individual products name.

In total also individual brand name (51.35\%) and company trade name combined with individual products name (29.72\%) are seen mostly used by consumer product industries of Nepal. It indicate that all the types of brands are not in balanced use. 
Table 2

Value of brand to the company

\begin{tabular}{|c|c|c|c|c|c|c|c|c|}
\hline \multirow[b]{2}{*}{ S.N. } & \multirow[b]{2}{*}{ Product Group } & \multicolumn{4}{|c|}{ Scale } & \multirow[b]{2}{*}{ Total } & \multirow{2}{*}{$\begin{array}{c}\text { Weighted } \\
\text { mean } \\
\text { value }\end{array}$} & \multirow[b]{2}{*}{ Rank } \\
\hline & & $\begin{array}{c}\text { Strongly } \\
\text { disagree } \\
1\end{array}$ & $\begin{array}{c}\text { Disagree } \\
2\end{array}$ & $\begin{array}{c}\text { Agree } \\
3\end{array}$ & $\begin{array}{c}\text { Strongly } \\
\text { agree } \\
4\end{array}$ & & & \\
\hline 1. & Soap & $\begin{array}{l}- \\
(0)\end{array}$ & $\begin{array}{c}- \\
(0)\end{array}$ & $\begin{array}{c}4 \\
(40)\end{array}$ & $\begin{array}{c}6 \\
(60)\end{array}$ & $\begin{array}{c}10 \\
(100)\end{array}$ & 3.60 & 2 \\
\hline 2. & Biscuit & $\begin{array}{c}- \\
(0)\end{array}$ & $\begin{array}{c}- \\
(0)\end{array}$ & $\begin{array}{c}4 \\
(50)\end{array}$ & $\begin{array}{c}4 \\
(50)\end{array}$ & $\begin{array}{c}8 \\
(100)\end{array}$ & 3.50 & 3 \\
\hline 3. & Noodles & $\begin{array}{c}- \\
(0)\end{array}$ & $\begin{array}{l}- \\
\text { (0) }\end{array}$ & $\begin{array}{c}5 \\
(83.33)\end{array}$ & $\begin{array}{c}1 \\
(16.67)\end{array}$ & $\begin{array}{c}6 \\
(100)\end{array}$ & 3.16 & 4 \\
\hline 4. & Cigarette & $\begin{array}{l}- \\
(0)\end{array}$ & $\begin{array}{l}- \\
(0)\end{array}$ & $\begin{array}{l}- \\
(0)\end{array}$ & $\begin{array}{c}5 \\
(100)\end{array}$ & $\begin{array}{c}5 \\
(100)\end{array}$ & 4.00 & 1 \\
\hline 5. & Cold Drink & $\begin{array}{c}- \\
(0)\end{array}$ & $\begin{array}{l}- \\
\text { (0) }\end{array}$ & $\begin{array}{c}- \\
(0)\end{array}$ & $\begin{array}{c}3 \\
(100)\end{array}$ & $\begin{array}{c}3 \\
(100)\end{array}$ & 4.00 & 1 \\
\hline & Total & $\begin{array}{l}- \\
(0)\end{array}$ & $\begin{array}{l}- \\
(0)\end{array}$ & $\begin{array}{c}13 \\
(40.62)\end{array}$ & $\begin{array}{c}19 \\
(59.37)\end{array}$ & $\begin{array}{c}32 \\
(100)\end{array}$ & & \\
\hline
\end{tabular}

According to above table 2, most of the consumer product industries agree that brand is valuable for a company for brand equity, product differentiation, market segmentation, new product introduction, pricing, promotion, distribution etc., because the mean value of all products is above the average level.

Considerations for effective branding of new products responsed by respondents are:

SOAP: (a) suitable to quality (b) Consumer awareness (c) Easy to advertise

(d) Effective and unique name (e) Brand name easy to say \& ask (f) Easy to communicate (g) Referential (h) Peculiar name (i) Socially acceptable.

BISCUIT: (a) Short name in one word (b) Common to all customer (c) Product differentiation (d) Easy in publicity (e) Easily communicable and referential (f) Socially acceptable.

NOODLES: (a) Easy for advertisement and publicity (b) Easy to remember (c) Attraction to customer (d) Different from other competitive brand (e) Creation of prestige (f) Easily pronounceable (g) Famous word (h) Consumer acceptable.

CIGARETTE: (a) Good name (b) Good image (c) Respect to social norms and values (d) Good effect on society (e) Culturally adjustable (acceptance).

COLD DRINK: (a) Creation of company's image (b) referential to product (c) effectively communicative to target group (d) consumer's choice (e) easy to advertise (f) acceptable in market by society. 
Table 3

Poor packaging is one of the cause of product failure

\begin{tabular}{|c|c|c|c|c|c|c|c|c|}
\hline \multirow[b]{2}{*}{ S.N. } & \multirow[b]{2}{*}{ Product Group } & \multicolumn{4}{|c|}{ Scale } & \multirow[b]{2}{*}{ Total } & \multirow[b]{2}{*}{$\begin{array}{l}\text { Weight-ed } \\
\text { mean value }\end{array}$} & \multirow[b]{2}{*}{ Rank } \\
\hline & & $\begin{array}{c}\text { Strongly } \\
\text { disagree } \\
1\end{array}$ & $\begin{array}{c}\text { Disagree } \\
2\end{array}$ & $\begin{array}{c}\text { Agree } \\
3\end{array}$ & $\begin{array}{c}\text { Strongly } \\
\text { agree } \\
4\end{array}$ & & & \\
\hline 1. & Soap & $\begin{array}{c}- \\
(0)\end{array}$ & $\begin{array}{c}- \\
(0)\end{array}$ & $\begin{array}{c}1 \\
(10)\end{array}$ & $\begin{array}{c}9 \\
(90)\end{array}$ & $\begin{array}{c}10 \\
(100)\end{array}$ & 3.90 & 2 \\
\hline 2. & Biscuit & $\begin{array}{c}- \\
(0)\end{array}$ & $\begin{array}{c}- \\
(0)\end{array}$ & $\begin{array}{c}3 \\
(37.50)\end{array}$ & $\begin{array}{c}5 \\
(62.50)\end{array}$ & $\begin{array}{c}8 \\
(100)\end{array}$ & 3.62 & 4 \\
\hline 3. & Noodles & $\begin{array}{c}- \\
(0)\end{array}$ & $\begin{array}{c}- \\
(0)\end{array}$ & $\begin{array}{c}1 \\
(16.67)\end{array}$ & $\begin{array}{c}5 \\
(83.33)\end{array}$ & $\begin{array}{c}6 \\
(100)\end{array}$ & 3.83 & 3 \\
\hline 4. & Cigarette & $\begin{array}{c}- \\
(0)\end{array}$ & $\begin{array}{c}- \\
(0)\end{array}$ & $\begin{array}{c}- \\
(0)\end{array}$ & $\begin{array}{c}5 \\
(100)\end{array}$ & $\begin{array}{c}5 \\
(100)\end{array}$ & 4.00 & 1 \\
\hline 5. & Cold Drink & (0) & (0) & $\begin{array}{c}2 \\
(66.67)\end{array}$ & $\begin{array}{c}1 \\
(33.33) \\
\end{array}$ & $\begin{array}{c}3 \\
(100) \\
\end{array}$ & 3.33 & 5 \\
\hline & Total & $\begin{array}{c}- \\
(0)\end{array}$ & $\begin{array}{c}- \\
(0)\end{array}$ & $\begin{array}{c}7 \\
(28) \\
\end{array}$ & $\begin{array}{c}25 \\
(72)\end{array}$ & $\begin{array}{c}32 \\
(100) \\
\end{array}$ & & \\
\hline
\end{tabular}

According to above table 3, all the sampled consumer product industries agree that poor packaging is one of the causes of product failure, because the mean value of all products is above the average level.

All the respondents $(100 \%)$ of the consumer product industries agree that packaging should attract attention, describe the product features, create consumer confidence and make a favorable impression, protection of the product, offers convince to the consumer and helps on company's promotional effort.

Table 4

Percent of packaging cost with compared to total cost

\begin{tabular}{|c|c|c|c|c|}
\hline S.N. & Product Group & Response percent & $\begin{array}{c}\text { No. of re- } \\
\text { sponse }\end{array}$ & $\begin{array}{c}\text { Average } \\
\text { percent }\end{array}$ \\
\hline 1. & Soap & $8+8+10+10+10+3+3+5+5$ & 9 & 6.88 \\
2. & Biscuit & $15+15+15+15+15$ & 5 & 15.00 \\
3. & Noodles & $10+10+8+8+16+5$ & 6 & 9.50 \\
4. & Cigarette & $20+20+20$ & 3 & 20.00 \\
5. & Cold Drink & $30+35+40$ & 3 & 35.00 \\
\hline & Total & & 26 & \\
\hline
\end{tabular}

Note : Av. Percent $=$ Response Percent/No. of Response

According to above table 4 , the average packaging cost of soap is $6.88 \%$, biscuit $15 \%$, noodles $9.50 \%$, cigarette $20 \%$ and cold drink $35 \%$ of total cost. The packaging cost 
of cold drink, cigarette and biscuit is higher respectively with compared to noodles and soap.

\section{Packaging \& Labeling Status of New Products}

The study further investigates the new consumer product packaging and labeling status in manufacturing units. They are aware about the value of packaging and labeling. They use these aspects for protection, promotion, guidance and so on.

As per the information found from the sample respondents all the consumer product industries $(100 \%)$ pay attention for effective packaging of new products. Majority of the consumer products $84.37 \%$ (27 out of 32 responses) are using product label as a simple tag attached to the product or an elaborately designed graphic that is part of the package.

\section{Table 5}

Description (subject matter) of product label

\begin{tabular}{|c|c|c|c|c|}
\hline \multirow{2}{*}{ S.N. } & \multirow{2}{*}{ Product Group } & \multicolumn{2}{|c|}{ Responses } & \multirow{2}{*}{ Total } \\
\hline & & Yes & No. & \\
\hline 1. & Soap & $\begin{array}{c}10 \\
(100)\end{array}$ & $\begin{array}{c}- \\
(0)\end{array}$ & $\begin{array}{c}10 \\
(100)\end{array}$ \\
\hline 2. & Biscuit & $\begin{array}{c}8 \\
(100)\end{array}$ & $\begin{array}{c}- \\
(0)\end{array}$ & $\begin{array}{c}8 \\
(100)\end{array}$ \\
\hline 3. & Noodles & $\begin{array}{c}6 \\
(100)\end{array}$ & $\begin{array}{c}- \\
(0)\end{array}$ & $\begin{array}{c}6 \\
(100)\end{array}$ \\
\hline 4. & Cigarette & $\begin{array}{c}5 \\
(100)\end{array}$ & $\begin{array}{c}- \\
(0)\end{array}$ & $\begin{array}{c}5 \\
(100)\end{array}$ \\
\hline 5. & Cold Drink & $\begin{array}{c}3 \\
(100)\end{array}$ & $\begin{array}{c}- \\
(0)\end{array}$ & $\begin{array}{c}3 \\
(100)\end{array}$ \\
\hline & Total & $\begin{array}{c}32 \\
(100)\end{array}$ & $\begin{array}{c}- \\
(0)\end{array}$ & $\begin{array}{c}32 \\
(100)\end{array}$ \\
\hline
\end{tabular}

According to above table 5 all the consumer products are using product label to describe that who made it, where it was made, when it was made, what it contains and how to use it. Sampled consumer product manufacturing units $(81.25 \%)$ agree that the consumers are guided by the label to use the new product. It is helping to the buyers to know about the ingredents, price, manufacturing and technical informations.

\section{Results and Implications}

New consumer products branding, packaging and labeling are important aspects for market success. The status of Nepalese manufacturing units and required implication regarding these aspects are as follows: 
1. Brand is important and its strategy is in consideration in the units. Product branding is valuable for brand equity, product differentiation, market segmentation, new product introduction, pricing, promotion etc. Brand name using plan implementation must be effective in the units.

2. So far use of brand name is concerned, majority manufacturing units are using individual brand name. Company trade name combined with individual products name is found in second highest use. Brand suitability judgment must be based on scientific approach.

3. Main considerations for branding the products are referential, unique, culturally acceptable, short, different from the competitors, easily communicable, able to create good image etc. Brand name has to be chosen on the basis of nature of products to be offered to the market and understanding/perception level of potential buyers.

4. All the marketing units pay attention for good packaging. They accept that poor packaging is one of the causes of product failure in the market. Generally packaging cost of cold drinks and cigarettes is higher with compared to other sampled products. It is necessary to set the packaging standard and to implement accordingly for better protection and promotion of a product.

5. Consumer new product manufacturers mostly use the label in their products. Basically they describe that who made it, where it was made, when it was made, what it contains, how to use it etc. Further more they believe that the consumers are properly guided by label to use the products. The information given in the label and its value have to be highlighted while promoting the product in the market. It must also be more useful technically.

\section{References}

Agrawal, Govinda Ram. Fundamental of Marketing A Nepalese Perspective Kathmandu:M.K.Publishers and Distributors, 2004.

Crawford, C. Merle. New Products Management. $3^{\text {rd }}$ ed. Homewood: Bosten Irwin, 1991.

Johne, Axel and Patricia Shelson. Successful Product Development. Oxford: Basil Blackwell Ltd., 1990.

Kotler, Philip \& Gary Armstrong. Principles of Marketing. New Delhi; Prentice-hall of India Pvt. Ltd., 2005.

Kotler, Philip. Marketing Management Analysis, Planning, Implementation, and Control. 8th ed. New Delhi:

Prentice-Hall of India Pvt. Ltd., 1996.

Koirala , K.D. Fundamentals of Marketing Decisions,Kathmandu; M.K.Publishers and Distributors,2005.

Mujumder, Ramanuj. Product Management in India. New Delhi: Prentice-Hall of India, 1993.

Stanton, William J. and Charles Futrell. Fundamentals of Marketing. Chicago: McGraw-Hill Book Co., 1991.

Boush, David M. and Barbara Loken. “A Process-Tracing Study of Brand Extension Evaluation.” Journal of

Marketing Research. XXVIII. (Feb. 1991): 16-28.

Cooper, Robert G. "New Products: The Factors That Drive Success." International Marketing Review. 11 No 1. (1994): 60-76.

Gatignon, Hubert, Barton Weitz and Pradeep Bansal. "Brand Introduction Strategies and Competitive 
Environments.” Journal of Marketing Research. XXVII. (Nov. 1990): 390-401).

Kamath, Rajan R. and Jeffrey K. Liker. “A Second Look at Japanese Product Development.” Harvard Business Review. 72. (Nov.-Dec. 1994): 154-170.

Keller, Kevin Lane and David A. Aaker. "The Effect of Sequential Introduction of Brand Extensions." Journal of Marketing Research. XXIX. (Feb. 1992): 35-50.

Lehmann, Donald R. and Yigang Pan. „Context Effects, New Brand Entry and Consideration Sets.“ Journal of Marketing Research. XXXI. (Aug. 1994): 364-374.

Maruca, Regina Fazio and Amy L. Halliday. "When New Products and Customer Loyalty Collide.” Harvard Business Review. 71. (Nov-Dec. 1993): 22-33.

Ohmae, Kenichi. "Managing Innovation and New Products in Key Japanese Industries.” Research-Technology Management. XXVIII no 4. (July-Aug. 1985): 11-17.

Pan Yigang and Donald R. Lehmann. "The Influence of New Brand Entry on Subjective Brand Judgments." Journal of Consumer Research. 20 no 1. (June 1993): 76-86.

Sarin, Sharad and Gour M. Kapur. “Lessons From New Product Failures: Five Case Studies.” Industrial Marketing Management. 19 no 4. (Nov. 1990): 301-313.

Sheinin, Daniel A. and Bernd H. Schmitt. "Extending Brands with New Product Concepts: The Role of Category Attribute Congruity, Brand Affect, and Brand Breadth.” Journal of Business Research. 31 no 1. (Sept. 1994): 1-10.

Zinkhan, George M. and Claude R. Martin, Jr. "New Brand Names and Inferential Beliefs: Some Insights on Naming New Products.” Journal of Business Research. 15 no 2. (Apr. 1987): 157-172.

Verma, Sandeep. "Marketing Strategy for the Launching of Branded Commodity- Basmati Rice" (Unpublished Dissertation) Delhi: Faculty of Management, University of Delhi, 1992. 